\title{
Metastatic Esophageal Squamous Cell Carcinoma
}

National Cancer Institute

\section{Source}

National Cancer Institute. Metastatic Esophageal Squamous Cell Carcinoma. NCI

Thesaurus. Code C156075.

A squamous cell carcinoma that arises from the esophagus and has metastasized to another anatomic site. 